УДК 16:165.74

DOI https://doi.org/10.32837/apfs.v0i27.920

\author{
М.В. Сінельнікова \\ ORCID ID: https://orcid.org/0000-0001-6085-6087 \\ кандидат філософських наук, доцент, \\ доцент кафедри філософії \\ Національного університету «Львівська політехніка»
}

\title{
НЕСТЕРПНА «ВАЖКІСТЬ» БУТТЯ АБО ІДЕЯ ВІЧНОГО ПОВЕРНЕННЯ У ФІЛОСОФІЇ Ф. НІЦШЕ
}

Постановка проблеми. М. Кундера з перших сторінок свого відомого твору «Нестерпна легкість буття» звертається до ніцшеанської ідеї вічного повернення, наголошуючи на тому, що вона настільки «загадкова, що нею Ніцше увігнав в замішання інших філософів» [8, с. 9]. В цьому він був абсолютно правий, адже що тільки в подальшому не робили з цією ідеєю: ï ігнорували, нівелювали, підміняли, раціоналізували, навіть заперечували. Мабуть, жодна інша ідея Ф. Ніцше не ставала «об’єктом таких численних сумнівів, спростувань і навіть нападів обурення і насмішок» $[12$, с. 174], як ідея вічного повернення. Це пов'язано перш за все 3 тим, що вона і сьогодні залишається одним 3 незавершених та найменш прояснених ніцшеанських концептів.

Велика кількість мислителів XX ст. та XXI ст. присвячували їй свої грунтовні трактати, пропонуючи власні оригінальні інтерпретації ніцшеанського вічного повернення, щоразу відкриваючи в ньому нові грані та нові горизонти бачення для людини. До їх числа можна віднести дослідження М. Хайдеггера, В. Кауфмана, Ж. Батая, Х.Л. Борхеса, Н. Аббаньяно, А. Боймлера, Ж. Дельоза, К. Льовіта, А. Данто, С. Шаапа, Т. Лютого, Маркова, В. Фарітова, М. Можейко, С. Жигалкіна. Така велика кількість інтерпретацій нерідко викликає розгубленість і деколи дуже далеко відводить дослідників від оригінальної ніцшеанської концепції, тому метою статті є дослідження ідеї вічного повернення через аналіз її основних аспектів (онтологічного, космологічного, метафізичного, антропологічного тощо), а також аналіз її зв'язку з іншими ключовими концептами Ф. Ніцше, такими як надлюдина, «смерть Бога» та воля до влади.

Виклад основного матеріалу. Витоки ніцшеанського вчення про вічне повернення зазвичай знаходять в античній філософії. Також згадки про нього можна віднайти в давніх єгиптян, індійській та перській міфології, буддизмі, позитивізмі та єретичних ученнях. 3 огляду на це оригінальність ніцшеанської ідеї може бути поставлена під сумнів, адже на перший погляд може видатися, що «філософ не сказав нічого нового, а лише повторив і відновив те, що було відомо за кілька століть і тисячоліть до нього» [14, с. 58]. Однак це лише на перший погляд. Насправді саме Ф. Ніцше можна по праву вважати «співцем» вічного повернення, бо лише він із таким завзяттям схопився за цю незвичну ідею, перетворивши її на той фундамент, на якому вибудовується уся його філософська система і до якої відходять своїм корінням всі інші його ключові ідеї.

Для правильного їі розуміння необхідно зібрати усі думки, висловлені Ф. Ніцше щодо вічного повернення. Його ключове пояснення міститься в "Eсcе Homo", а в подальшому уточняється та доповнюється в роботі «Так говорив Заратустра». $€$ також кілька згадок про нього у «Веселій науці» та «По той бік добра і зла». Більше вчення про вічне повернення не зустрічається в жодному з опублікованих творів Ф. Ніцше. Цим пояснюються неузгодженість та протиріччя в міркуваннях філософа стосовно цього концепту, оскільки більша ix частина має фрагментарний характер.

$\Phi$. Ніцше не подає вічне повернення як теоретичну ідею, філософську тезу чи гіпотезу, замість цього він «пропонує притчу, яка лежить в області уяви" [10, с. 592]. Мислитель цілком свідомо вибирає саме таку форму викладу, оскільки для обгрунтування ідеї вічного повернення як природничо-наукової теорії у нього не було достатньої кількості наукових аргументів. Крім цього, $\Phi$. Ніцше хотів долучити читача до сфери емоційного сприйняття світу, оскільки лише так можна вловити сутність цієї ідеї, а саме через «озаріння» та «одкровення», через екзистенціальний досвід, як це зробив сам філософ.

Однак справжнім джерелом рецепції вчення про вічне повернення служать матеріали Чернеток філософа або "Nachlass" (спадщина (нім.)). Тут Ф. Ніцше докладно розробляє онтологічний, космологічний, метафізичний, антропологічний, екзистенціальний та інші аспекти свого вчення. Саме за умови утримання суперечливого поєднання цих різноманітних аспектів концепт вічного повернення може бути адекватно сприйнятим, тому в ніцшеанському вченні одночасно поєднуються галузь онтології та етики, космології та антропології, метафізики та аксіології, які пронизуються духом екзистенціалізму. Об'єднання усіх цих елементів в єдине ціле допомагає повніше збагнути сутність ніцшеанського концепту вічного повернення. Оскільки амбівалентність та вну- 
трішня суперечливість цієї ідеї не мають діалектичного характеру, а «зняття і синтезу протиріч тут не відбувається» [14, с. 55], тому ізолювання чи абсолютизація одного з моментів вічного повернення приводить до помилки догматизації або релятивізації всього вчення.

Почати варто з онтологічного аспекту вічного повернення, який описує та передає «рактичні» ознаки реальності, що відходять своїм корінням до природничо-наукових позитивістських ідей, представлених Є. Дюрінгом у книзі «Курс філософії» (1875 рік). Під їх впливом Ф. Ніцше стверджує, що «світ володіє певною кількістю сили і певною кількістю центрів сили <...>, з чого випливає, що випадає нескінченна кількість комбінацій у величній грі в кістки в ході світового розвитку. За нескінченний час всі можливі комбінації вже повинні були випасти, більше того, кожна з них повинна була випадати нескінченну кількість разів. Отже, між кожною комбінацією і її повторенням всі попередні комбінації повинні бути пройдені, і кожна 3 цих комбінацій визначає всю послідовність комбінацій. Світовий цикл вже безліч разів повторював самого себе» [21, с. 135-136]. Така інтерпретація демонструє конечність елементів в нескінченному часі, або, як переконливо зазначає Ясперс, конечність простору, i одночасно безконечність (i «в-собі-буттєвість») часу [17, с. 478-479].

Вічне повернення постає як онтологія циклічного часу, який скасовує минуле та майбутнє, залишаючи тільки теперішне, лише цю конкретну «мить», застиглу у вічності. Це виводить нас на космологічний аспект вічного повернення, згідно 3 яким «світ завершений в кожний новий момент і в кожний новий момент досягає свого кінця [Ende]» [18, с. 319], або, як зазначає сам Ф. Ніцше, «довкола кожного "Тут» перекочується куля «Там»» [13, с. 217-218]. Так філософ стирає усі кордони між конечним і нескінченним, тимчасовим і вічним, іманентним і трансцендентним, тому в ніцшеанському колі вічного повернення все єдине, все одне й те ж, все відбувається одночасно, без початку і кінця, без порядку і досконалості у світі, в якому панує непередбачувана випадковість. Це положення фактично утверджує фундаментальну безглуздість існування: якщо в результаті все повертається і не відбувається ніяких змін, то буття не має сенсу.

Це приводить нас до антропологічного моменту вічного повернення і підтверджує думку Н. Аббаньяно про те, що «антропологія і космологія були завжди тісно пов' язаними у думці Ніцше» [1, с. 43]. Постійне повернення беззмістовної миті може розчавити людину, зруйнувавши іiі волю до життя. Це підтверджує сам Ф. Ніцше: «Щойно це питання (вічного повернення) наляже на тебе, як «найбільший тягар», воно змінить тебе» [20, с. 250]. Ф. Ніцше не випадково називає свою ідею вічного повернення «найбільшим тягарем», бо якщо наші життя нескінченно повторюються, то людина відтепер постає прикутою до вічності i на кожному іï вчинку лягає неймовірний тягар відповідальності, що підсилює вагомість її рішень та помилок.

Однак це лише одна сторона ніцшеанської ідеї, яка вирізняється своєю амбівалентністю, адже, з одного боку, вона може викликати у людини апатію, зумовлену втратою сенсу життя, а з іншого боку, вона може спонукати прийняти «виклик», на тлі якого особистість перевершує себе, виходячи не тільки на інший рівень тілесної та ментальної організації, але й на новий щабель мислення, тому, як говорить Ф. Ніцше, «нехай все неперервно повертається. Це найвищий ступінь зближення між майбутнім і теперішнім, у цьому вічному повторенні - найвища точка мислення!» [19, с. 133]. Так, в ідеї вічного повернення починають проступати екзистенціальні мотиви, які відкривають перед людиною абсолютно нову перспективу, з «далечини якої речі постають в іншому, небаченому досі світлі; постають без пом' якшуючої обставини своєї скороминущості» [8, с. 10].

Це дає змогу особистості сприймати нестерпну «важкість» свого буття як певну перешкоду, яку вона щоразу радісно долає. Так у Ф. Ніцше ідея вічного повернення перетворюється на вище утвердження існування, яке приховує головну радість буття: світ повертається знову і знову, життя $\epsilon$, незважаючи ні на що, а нестерпна «важкість» буття вічного повернення несподівано перетворюється на любов до себе і невимовну радість, принаймні для окремої людини, тому хоча вічне повернення і виступає важким тягарем, проте на його фоні наші життя можуть постати перед нами у всій своїй неймовірній легкості. Таким дивовижним чином Ф. Ніцше, «відкопавши жахливу гіпотезу про вічне обертання, спробував перетворити цей інтелектуальний кошмар на привід для тріумфу» [4, с. 188]. Тут варто було б додати «на тріумф надлюдини», адже лише їй під силу витримати «тягар» вічного повернення.

Слід відзначити, що надлюдина трактується Ф. Ніцше як «шлях подолання «людини» взагалі, всього «людського» (особистого, звичного тощо)» [15, с. 217]. Ніцше і справді говорить не про вдосконалення людини, а про їі подолання: «Людина - це те, що треба подолати» [13, с. 8], а той, хто долає самого себе, стає надлюдиною (“bermensch"). Не даремно Ніцше-Заратустра вчить вічного повернення того ж «по той бік людини і часу» [9, с. 182], бо лише так, через відмову від надмірних людських почуттів і прагнень, особистість здобуває силу надлюдини.

«Подолання" також використовується у $Ф$. Ніцше як основна функція життя, яка привертає нашу увагу до постійної небезпеки, яка загрожує кожному, оскільки в колі вічного повернення 
постійно і неодмінно буде повертатися і «маленька людина», яка прагне буттєвого комфорту, тому в концепції Ф. Ніцше вона виступає і найбільшою спокусою, оскільки збиває людину з ї̈ «істинного шляху" до надлюдини, адже міститься всередині кожного $з$ нас. Таким чином, тут краще вимальовується ідея «подолання», а точніше, «самоподолання», бо ми повинні здолати цю «маленьку» людину в самому собі для власного «самоперевершення» .

В останній тезі головним моментом виступає неймовірне самовладання, яке має форму принципу, згідно з яким усе, зрештою, перевищить умови власного виникнення. Наслідком такого повороту є не формальне заперечення, а перетворення на щось принципово нове. На це звертає увагу В. Миронов, який наголошує на тому, що «фактично він (Ф. Ніцше) піддає нас ритуалу ініціації, в якому реалізується наша гранична самоактуалізація, граничне занурення в нашу самість. I тоді ми раптом виявляємо всередині себе якусь нову істоту, яка наполегливо розбиває стару шкаралупу, змушуючи нас максимально бути самим собою» [11, с. 169-170].

Звідси стає зрозумілим, чому в ніцшеанській ідеї вічного повернення немає ні прогресу, ні поступу, ні змін, адже сам "розвиток» людина проносить в самій собі. У зв'язку з цим Ф. Ніцше використовує влучний вислів «Стань тим, ким ти є» [20, с. 243], який пояснює цю сторону вчення філософа: людина в колі вічного повернення насправді не змінюється, вона стає самою собою. Саме тому ніцшеанське вічне повернення це - «не повторення, а повернення ... до самого себе» [7, с. 142], повернення людини до своєї власної сутності.

Цю сутність Ф. Ніцше визначає як волю до влади, адже вона - це «не те, чим ми володіємо, а те, чим ми є насправді» [5, с. 258]. Тут ми спостерігаємо дивовижний ніцшеанський «сплав», до складу якого входять світ становлення, світ вічного повернення та світ волі до влади. Саме ці елементи визначають суще в його бутті і виводять нас на метафізичний аспект вічного повернення. Розуміючи волю до влади як становлення, Ф. Ніцше вбачає в ній вічну гру стихійних сил природи та буття, в яку залучається людина в процесі свого сходження до надлюдини. Остання визначається Ф. Ніцше як «образ найчистішої волі до влади» $[12$, с. 174$]$, яка велить нам невпинно зростати через зростання волі до влади. Так ідея «вічного повернення все переводить у сферу суб'єктивного» [3, с. 15], адже саме вічне повернення затверджується вольовим актом суб'єкта. Ми самі прагнемо, щоб світ і всі його події поверталися.

Цьому сприяє «доленосна» подія, яку виголошує Ф. Ніцше, а саме «смерть Бога», яка є стає лише умовою вічного повернення, оскільки вона означає кінець сьогоднішнього світу і проголошення нового, усвідомленого в його просторово-часовій тотальності, тому гідного нескінченного повернення. Розмірковуючи над причинами «смерті Бога», $\Phi$. Ніцше доходить висновку, що його вбило «поневолення та використання на користь людини» [2, с. 264]. Вiра в Бога довгий час забезпечувала людську самоідентичність, але в ситуації його смерті дія принципу вічного повернення унеможливлює стабільну самоідентифікацію індивіда, який щоразу набуває нової іпостасі, тому ідея "смерті Бога» вивільняє прихований потенціал людини, в якої тепер немає іншої мети, крім самої себе. Таким чином, мета знаходиться не зовсім там, де ми звикли її бачити. Відтепер «мета людства лежить не в його кінці [Ende], а тільки в його найдосконаліших представниках» [18, с. 320]. В цьому сенсі надлюдина виступає долею світу, "смислом землі», «сутністю буття», що змушує їі постійно наділяти змістом земне існування.

3 одного боку, тут проявляє себе етичний аспект ідеї вічного повернення, який полягає в наданні людині категоричного імперативу: проживати щомиті так, щоб завжди можна було захотіти пережити все це знову. Оскільки людина, яка один раз пережила досвід вічного повернення, в подальшому змогла би подолати страх цього «страшного» ніцшеанського відкриття, або, як говорить сам німецький філософ "устами» Заратустри: «Оце й було життям? ... Гаразд! Живімо знову!» [13, с. 315]. 3 іншого боку, тут проявляється аксіологічний аспект вічного повернення, який накладає на людину завдання переоцінки цінностей, оскільки в ситуації смерті Бога вона стає морально незалежною і змушена знову стати мірою всіх речей [16, с. 133].

Вагоме місце у цьому Ф. Ніцше відводить творчості, оскільки вважає її невід'ємним моментом становлення. Людина виступає як творець, перш за все творець самого себе. На переконання $\Phi$. Ніцше, «слабкий шукає в житті сенсу, мети, завдання, наперед встановленого ладу; сильній людині вічне повернення служить матеріалом для творчості їі волі» [13, с. 165]. Це пояснюється у Ф. Ніцше онтологією волі до влади, тобто онтологією сил: "у речі стільки смислів, скільки існує сил, здатних нею заволодіти» [6, с. 39]. Таким чином, людина «сама наділяє своє життя сенсом, вдосконалюючи себе і радіючи кожному моменту» [18, с. 324]. Саме так вічне повернення відкриває людині нову істину та нову оптику, вказуючи їй шлях до сутності, змісту та таємниці буття.

Висновки. Очевидно, що Ф. Ніцше дуже серйозно ставився до вічного повернення, оскільки «передчував, що ця ідея повинна стати найголовнішою в його вченні, але одночасно і найжахливішою» [12, с. 171]. Однак чи дійсно вона настільки жахлива, як це видавалося Ф. Ніцше? Адже ще М. Кундера у своєму творі ставить доленосне питання «Чи дійсно важкість жахлива, а легкість 
приваблива?». Оскільки легкість у якийсь момент може стати нестерпною, а ставитися до життя безтурботно стає для людини надзвичайно "важко», тому хоча найважчий тягар може нас розчавити, проте чим він важчий, тим наше життя ближче до землі, тим воно реальніше і правдивіше. Навпаки, «абсолютна відсутність важкості веде до того, що людина стає легшою за повітря, злітає у вишину, відривається від землі, від земного буття, стає напівреальною, і її рухи настільки ж вільні, наскільки і безглузді» [8, с. 11].

Не даремно М. Кундера, вирішуючи дилему «важкість - легкість», звертається до ніцшеанської ідеї вічного повернення, яка фактично піднімає ті самі питання, які турбують кожну людину. Чому в її життя повертаються не тільки позитивні і приємні події, але й негатив, підлість та зрада? Як цього уникнути і як цьому зарадити? Відповідь $\Phi$. Ніцше очевидна: необхідно ставати сильнішим у цьому бурхливому і непередбачуваному потоці життя. Саме тому ніцшеанське вічне повернення означає волю до утвердження та прийняття усіх моментів існування, а мужність надлюдини проявляється в поверненні до своєї сутності, яка велить невпинно зростати, незважаючи на всі перепони.

Здійснене дослідження в подальшому допоможе розширити межі традиційного трактування ніцшеанської ідеї вічного повернення, відкриваючи нові горизонти, нові грані та нові аспекти їі тлумачення, висвітлюючи та прослідковуючи їі впливи на духовний стан сучасної людини та суспільства.

\section{Jimepamypa}

1. Аббаньяно Н. Мудрость философии / пер. с. ит. А. Зорина. Санкт-Петербург : Алетейя, 2000. 311 с.

2. Батай Ж. О Ницше / пер. с фр. А. Бакулов. Москва : Культурная революция, 2010. 336 с.

3. Боймлер А. Ницше философ и политик / пер. с нем. А. Игнатьева. Лейпциг, 1931. URL: http://www.nietzsche.ru/look/xxa/beumler.

4. Борхес Х.Л. Письмена Бога. Москва : Республика. $512 \mathrm{c.}$

5. Данто А. Ницше как философ / пер. с англ. А. Лавровой. Москва : Идея-Пресс: Дом интеллектуальной книги, 2001. 258 с.

6. Делёз Ж. Ницше и философия. Москва : Ад Маргинем, 2003. 392 с.

7. Жигалкин С. Метафизика вечного возвращения. Москва : Культурная революция, 2011. 256 с.

8. Кундера М. Невыносимая легкость бытия / пер. с чеш. Н. Шульгиной. Санкт-Петербург : Азбука-классика, 2002. 352 с.

9. Лёвит К. Ницшевская философия вечного возвращения того же / пер. с нем. В. Бакусева. Москва : Культурная революция, 2016. 336 с.

10.Лютий Т. Ніцше. Самоперевершення. Київ : Темпора, 2017.978 с.

11. Миронов В. Философия истории Фридриха Ницше. Вопросы философии. 2005. № 11. С. 163-175.
12. Можейко М. Вечное возвращение. История философии. Энииклопедия. Минск : Интерпрессервис ; Книжный Дом. 2002. С. 171-176.

13. Ніцше Ф. Так казав Заратустра. Жадання влади / пер. $з$ нім. А. Онишка, П. Таращука. Київ : Основи. Дніпро, 1993. 415 с.

14.Фаритов В. Идея вечного возвращения Ф. Ницше: между философией и поэзией. Философская мыссль. 2017. № 4. С. 55-69.

15. Хайдеггер М. Метафизическая концепция Ницше и ее роль в европейском мышлении. Вечное возвращение равного (Главы лекций 1936-1940-х годов). Метафизика вечного возвращения / С. Жигалкин. Москва : Культурная революция, 2011. С. 188-250.

16. Шаап С. Нездатність забувати: Новий погляд на питання про істину / пер. з нім. О. Кислюка. Київ : видво Жупанського, 2009. 294 с.

17.Ясперс К. Ницше. Введение в понимание его философствования / пер. с нем. Ю. Медведева. Санкт-Петербург : Фонд «Университет» ; Владимир Даль, 2004. 629 с.

18. Kaufmann W. Nietzsche: Philosopher, Psychologist, Antichrist. Princeton ; New Jersey : Princeton University Press, 2013. 560 p.

19. Nietzsche F. Der Wille zur Macht. Frankfurt : Voltmedia, Paderborn, 2015. $410 \mathrm{~s}$.

20. Nietzsche F. Die Fr hliche Wissenschaft. K ln : Anaconda, 2012.320 s.

21. Nietzsche F. Nachgelassene Fragmente 1882-1884. Berlin : de Gruyter, 1980. $336 \mathrm{~s}$.

\section{Анотація}

Сінельнікова М. В. Нестерпна «важкість» буття або ідея вічного повернення у філософії $\Phi$. Ніцше. Стаття.

У статті досліджено ніцшеанську ідею вічного повернення, яка вважається найбільш фундаментальною і найменш проясненою у філософії німецького мислителя. Зауважено, що їі сутність краще висвітлюють основні аспекти, які розглядаються Ф. Ніцше, а саме онтологічний, космологічний, антропологічний, метафізичний, екзистенціальний та аксіологічний. Констатовано, що лише в єдності ці аспекти допомагають краще збагнути сутність ніцшеанського концепту вічного повернення.

Зазначено, що онтологічний аспект вічного повернення описує «фактичні» ознаки реальності: все у світі повертається до того ж самого нескінченну кількість разів, тому буття нагадує своєрідний калейдоскоп, де щоразу випадають нові комбінації. Космологічний аспект вічного повернення передбачає нескінченність часу, в якому зливаються в одне ціле минуле та майбутнє, а миттєвість теперішнього ніби застигає у вічності.

Антропологічний аспект передбачає пошуки сенсу життя у нескінченному колі вічного повернення, який проступає у Ф. Ніцше в образі надлюдини, що визнається єдиним сенсом сущого і трактується філософом як становлення самої людини через зростання у ній волі до влади. Цьому сприяє "смерть Бога», виголошена Ф. Ніцше, адже саме вона дає людині можливість максимально проявити свій творчий потенціал через власне зростання та подолання в собі всього «низького» та «людського». 
Екзистенціальний аспект вічного повернення пропонує людині новий імператив існування, який закликає їі проживати кожну мить так, щоби бажати iii вічного повернення. Метафізичний аспект вічного повернення демонструє буття як становлення надлюдини та ії̈ волі до влади, яке визнається її невід’ємною сутністю. Аксіологічний аспект ніцшеанської ідеї вічного повернення наголошує на тому, що відтепер сама людина повинна стати «мірою» усіх речей і здійснити переоцінку цінностей. Підсумовано, що вчення Ф. Ніцше про вічне повернення, надлюдину і волю до влади, зрештою, зводяться до однієї єдиної формули, а саме людського «самовизначення» через самоперевершення та самоподолання.

Ключові слова: Ф. Ніцше, вічне повернення, «смерть Бога» воля до влади, надлюдина.

\section{Summary}

Sinelnikova M. V. The unbearable "difficulty" of existence or the idea of eternal recurrence in Nietzsche's philosophy. - Article.

The article examines the Nietzschean idea of eternal recurrence, which is considered the most fundamental and least clarified in the philosophy of the German thinker. It is noted that its essence is better covered by the main aspects considered by Nietzsche, namely: ontological, cosmological, anthropological, metaphysical, existential and axiological. It is stated that only in unity do these aspects help to better understand the essence of Nietzsche's concept of eternal recurrence.

It is noted that the ontological aspect of eternal return describes the "actual» signs of reality: everything in the world returns to the same infinite number of times, so being resembles a kind of kaleidoscope, where new combinations fall out each time. The cosmological aspect of eternal recurrence presupposes the infinity of time, in which the past and the future merge into one, and the instantaneity of the present seems to freeze in eternity.

The anthropological aspect involves the search for the meaning of life in the endless circle of eternal recurrence, which appears in Nietzsche in the image of the superman, recognized as the only meaning of being and interpreted by the philosopher as the formation of man himself through the growth of his will to power. This is facilitated by the "death of God" proclaimed by Nietzsche, because it gives a person the opportunity to maximize their creative potential, through their own growth and overcoming all the "low" and «human".

The existential aspect of eternal recurrence offers man a new imperative of existence, which calls him to live every moment so as to desire his eternal recurrence. The metaphysical aspect of eternal recurrence demonstrates being as the formation of the superman and his will to power, which is recognized as its integral essence. The axiological aspect of Nietzsche's idea of eternal recurrence emphasizes that from now on man himself must become the "measure» of all things and re-evaluate values. It is concluded that Nietzsche's doctrine of eternal recurrence, the superman, and the will to power are ultimately reduced to a single formula - human "selfdetermination", through self-transcendence and selfovercoming.

Key words: F. Nietzsche, eternal recurrence, "death of God", will to power, superman. 